\title{
An image of the book in Notes on Manuscripts and Old Books in Moldavia, I-IV, a corpus edited by I. Caproșu and E. Chiaburu
}

\author{
Maria Lupu* \\ Faculty of Letters, "Alexandru Ioan Cuza" University, Bd. Carol I 11, 700506 Iaşi, Romania
}

\section{Article info}

History:

Received November 22, 2014

Accepted January 10, 2015

Published July 17, 2015

Key words:

translation

marginalia

paratext

\begin{abstract}
The context in which this research takes place is within our broader concerns about the evolution of mentalities in the period after the sixteenth century. The purpose of this research is to identify, to some extent, how the people of that specific period related to the book. This requires a repeated and successive reading of the notes, each time with a different purpose, seeking for other data. The main instruments were analysis and synthesis, approached from a diachronic perspective. The approach is an inductive one, from particular to general. The fact is that, printed or manuscript, the book is an active factor in the human life and enjoys a high respect. First the spreading, then the diffusion of the books, followed by an extensive effort of translating into different languages, reflect a great cultural effervescence.
\end{abstract}

\section{Introduction}

The old notes on manuscripts and books, paratextual elements of the book itself, become a free-standing literature with a multidisciplinary nature, being the expression of the sensibility of an age in progress. Whether there are described situations of copying, selling and purchasing, donation and translation of the book, or historical events, weather, natural disasters, infectious diseases, they provide a fresco from a bygone age, being real sources (which are unique through their characteristics) for researchers in various fields. Among these, the notes that refer to the book stand out numerically, providing important information regarding the copyist, the owner, the book distribution and diffusion, the price, the reader, the reconditioning, the translation, donation, re-buying, etc. within the period 1429-1859.

\section{The book, a Christian dimension of time}

Books were regarded as lasting objects. The notes are recorded on the books because the latter ensure their durability. In a society where, up to a point, the orality rules, the writing becomes, as in Phædrus' myth, a "cure of forgetfulness and, equally, of ignorance" (Platon, 2011, p. 126). Due to the Christian message it contains, the books enjoy a special moral consideration and there is the belief that the volume/manuscript is intended for an eternal existence (Chiperi, 1996, p. 13). Once assigned to books and fixed by writing, this certainty stimulates the notes which become a connection with posterity, facing time by looking for a collocutor in future generations; hence the motif in the most marginal notes, "(in order) to be known". The material that contains the notes-the book as a durable object-ensures this complex dialogue between generations, and this article is a proof of this.

Related to the dimension time, the book reveals a deeply religious feeling of the people of that time, outlining, through its depiction in the perception of the community, a temporal dimension in the Christian sense (Radosav, 1997, p. 75). Once put in the lectern or in the temple, the worship book becomes immovable, escaping the trace of time (Ofrim, 2001, p. 129): "Stăpîna și cneaghina Theodora" (The Mistress Theodora) gave a Gospel to the Metropolitan Church of Suceava "neclintit în vecii vecilor, amin"

*Email address: marioaralupu@yahoo.com. 
Maria Lupu

(firm both now and ever, amen) (I, 24) ${ }^{1}$. In the middle of the $16^{\text {th }}$ century, the bishop Teofan also donates a book "ca să-i fie lui amintire pentru nesfîrșiţii veci" (to be for his memory into the ages) (I, 57). Sometimes the time of the book proves to be the time of the God's world (Radosav, 1997, p. 131). Thus, the monk Parthenie from the monastery Bisericani buys the Psalter "ca să fie în chilia mea, pînă cînd va milui Dumnezeu în această lume deșartă" (in order to be in my cell untill God shows His grace in this vain world) (I, 157). Because the book is considered to be "vecinică pomenire" (everlasting commemoration) for the donors' souls (II, 30), it is seen as the "key" to the world of the eternal happiness, a link between the mundane and the divine: those who have contributed to the acquisition of a "Chiriacodromion" are "scriși pi patruzăci di fili, spre pomenirea lor și a tot neamul lor, în veacul acesta și în celalalt ce va să fie" (written on forty sheets, for their and all their followers commemoration both now and never) (III, 126). The book is integrated into the complex of beliefs, of traditional customs meant to ensure the salvation of the soul and it is a way of strengthening the solidarity of the living world and the ancestors' world (Radosav, 1997, p. 76). The book is bought in order to "ca să fei odoru în veci feciorilor mei și nepoțîlor și strănepoților” (be forever a treasure for my sons and my grandsons and my great-grandsons) (III, 304), with the confidence that it benefits the same appreciation.

The marginal note is seen another temporal dimension. The act of writing is a symbol of the eternity; being always opposed to the essence of the human nature, a tension appears between "mîna de țărînă" (the hand of dust) (a synecdoche for the frailty of human nature in general) and "slova veșnică" (the everlasting word) within the marginal notes: "Și mîna care au scris va putrezi în groapă, iar cuvintele vor rămînea în veci, amin" (And the hand that wrote would rot in grave and the words would stay forever, amen) (II, 222). The priest Vasile Baltag writes the holder's name "spre pomenirii și spre ținere de minte, că oamenii să pitrec, dar sfintele cărți rămîn” (for commemoration, because the existence of the people is temporary, but the holy books stay forever) (IV, 392). The act of writing can also be used to the detriment of the sinners. Thus, in a poem about meditation on death of the late $18^{\text {th }}$ century, the sins cannot be neither "dosnicite" (hidden) nor denied, because they "sînt scrise prin izvoade/[...] Să rămîî în vecii” (are registered / [...] in order to be remembered forever) (II, 319).

\section{Features of the book}

"Sfîntă și dumnezeiască" (Holy and divine) (II, 347), the book was treated as a worship object along with other valuable objects which served to the religious ritual, being included in "catastiful de odoare bisericești" (the register of the ecclesiastical objects) (I, 97) belonging to the treasure of the holy place: "argintării, veșminte, cărți și alte lucruri” (silvery, clothes, books and other things) (IV, 103).

The books contain notes which summarize their value. The Tarlo's History is "vrednică de citit" (worth reading) (III, 472), another book is "foarte iscusită și frumoasă" (very artistic and beautiful) (III, 58) and a Bertoldo seemed to Iordache Chirescu "atîta de interesătoare şi bine tocmită" (so interesting and well written) that he considered it worthy of a "de o tălmăcire moldovenească” (translation into Moldavian) (II, 541). The accumulation of juxtaposed or copulative coordinated superlatives shows sometimes a studied eloquence: "preaînaltă, preaminunată și de mare și negrăit folos pricinuitoare carte" (a book all-high, sublime and of great and unspeakable use) (IV, 479). The utility of the book is often stated within the marginal notes. A religious tome is "de mult folos oamenilor" (of great benefit to people) (III, 18) and one of D. Cantemir's writing is "foarti folositoari oricui să va îndeletnici a citi" (very useful to anyone who reads it) (III, 364); the determiner "useful" used for the book can be circumscribed both to the religious pedagogy and to the use of the volume as a textbook (Radosav, 1997, p. 27). Regarding the human dimensions, the book is "folositoare sufletești și trupești" (helpful for the soul and the body) (IV,

\footnotetext{
${ }^{1}$ Due to their frequency, the references to Insemnări de pe manuscrise și cărți vechi din Țara Moldovei will be marked as follows: within round brackets we will give the volume number with Roman numerals, followed by the page number with Arabic numerals.

${ }^{a}$ An orthodox worship book.
} 
94), but especially for "folositoare de suflete" (souls' help) (III, 480). At the same spiritual level, it is "izbăvitoare de suflet" (saving souls) (I, 155), being a "balțăm vindicatoriu din munca di veci și împărăţia ceriului" (healing balm for the eternal torment and kingdom of heaven) (IV, 228), an open way to the sins salvation.

The book is sometimes metaphorized. In a metaphorical "definition", the genus (proximus) compares a Gospel (Evangheliar) to the musical instruments: "această [de] b(la)goslovie cu patru strune" (this four strings blessing), while the specific difference brings the necessary explanation: "şi cu tot dulcele glas alăută" (with a sweet violin voice) (I, 475). In other cases the missing feature is stated in the first place: "cartea nu iaste lucru pămîntesc" (the book is not an earthly thing), and thus it keeps away the common techniques to act upon it: "ca să-l cioplești cu barda" (to cut it with an axe); on the contrary, "iaste duhu datu de la $\mathrm{D}(\mathrm{u}) \mathrm{mn}(\mathrm{e})$ dzău” (the book is God's spirit), the right tool for its accomplishment being the reason: "ca să-l lucrezi cu mintea" (to work it with the mind) (I, 528). Thus it is stated the sanctity of the act of writing, the (religious) book being a hierophany (Radosav, 1997, p. 68), an object through which the divine manifested. The metaphor of the book as a flower is also frequent, but not a "îndegrab veștejitoare și putrezitoare" (fast fading away one), but "îndelung trăitoare și mirositoare [...] udate din rooa darului Duhului Sfint" (of long time living and sweet-smelling flower, washed by the Holy Spirit's dew) (II, 426), flower which can be smelled and tasted. And the receiver's taste buds will be delighted by "dulciața aceștii Svinte Scripturi" (the sweetness of this Holy Scripture) (I, 475), the reader will "adăpa sufletul" (please his soul) with "multi dulci învăţături” (many sweet teachings) (III, 284), because the book is a "izvor de miere" (source of honey) (II, 127) or a "dătătoare de miere și aur" (honey and gold giver) (I, 166). In the medieval metaphors, the topos of the book as food (widespread in Western literature) has its origins in the Old Testament books (Ezekiel's vision, Saint John's one), where the bibliophagy is a form of consubstantiality of the man with the book (Ofrim, 2001, p. 213). What Jack Goody calls "the drinking of the word" (Ofrim, 2001, p. 213), the symbol of swallowing the text is a way to remove the distance between the reader and the written text.

\section{The transcriber}

The overwhelming majority of the marginal texts records the copying of the manuscript. The manuscript is a permanent presence of the time in question, initially as the only means of multiplication, then invested with new functions. In contrast to the printing houses, which are monopolized by the state, the selfmanuscript edition signifies the freedom of the educated ones to choose their own readings and to spread them without referring to the state and without seeking the approval of any political or ecclesiastical figures (Barbu, 1996, p. 76).

Most of the times the manuscript is signed because those who took great pains to copy it didn't want to remain anonymous. The transcriber's complete name-or even followed by different determiners which eliminate the possibility of confusion-follows some deprecatory epithets: the "Syntagma" of Matthew Blastares is written "cu mîna multpăcătosului tahigraf, grămătic Damian" (by the hand of the too sinful stenographer and clerk Damian) (I, 20). Modesty becomes a stereotype, but there are cases when it creates sugestive images: "S-au scris di păcătosul Simion, cel mai păcătos dicît toți păcătoșii și mai rău dicît dracii și mai viclean și mai bețiv, curvar pre curva Sodomii, tîlhar, fur... și în vîrfu răutăților ajuns” (It is written by the sinner Simion, the most sinful among sinners and worse than all devils and more malicious and drunkard, whore, thief, who reached the top of the evils) (III, 474).

Starting with the $15^{\text {th }}$ century and until the middle of the $19^{\text {th }}$ century, the signature on the manuscript contains frequently a specific pattern: a Gospel is copied "cu mîna multpăcătosului moldovean" (by the hand of a too sinful Moldavian) (I, 13); "Scrisu-s-au această carte di această di lut păcătoasă mînă a me" (this book was been copied by my earthly miserable hand) (II, 392). The right hand often stands for the "hand": "S-au prescris prin osîrdie dreptii mele" (It was copied with the pain of my right hand) (III, 360). Both the founding intention and the work belong to a founder, but the performing (the "hand" 
synecdoche) belongs to the qualified worker (a transcriber in this particular case). In medieval culture "the hand" is the source of all that exists, the very source of human creativity (Barbu, 1996, p. 100).

Many transcribers belong to the ecclesiastical world, from petty clergymen to the bishops and patriarchs. Other books were copied by various clerks: "S-au sfîrșit Istorie Sfintului Avva Macarie. Martie 31, 1789, i proci. Logofăt Ilie Gligorcea” (The History of Saint Macarius the Great is finished. March 11, 1789, i proci. Chancellor Ilie Gligorcea) (II, 479), where the words in old Slavonic confirm the scribe position of the author. But the transcribers are also members of other social categories; various manuscripts are copied by high officials, persons working in military service (captains), servants or pages. Those who copy the books call themselves "writers" or even "copyists". It should also be noted that many manuscripts have women-authors, all of them belonging to the monastic environment: a Miscellany was copied by "scri-s-au de [...] nevrednica shimonahia Micdonia" (unworthy nun Micdonia) (III, 2), and another one "s-au scris de Ipistimia monahia" (is copied by nun Ipistimia) (III, 12).

The manuscripts are transcribed when ordered by someone who wants the book, at his cost. Especially the books dating from the $15^{\text {th }}$ and $16^{\text {th }}$ century are copied under the royal patronage, either ordered by a prince or by the members of the royal family. The rulers initiated and actively supported the endowment of the churches with the necessary religious texts, wanting them to be a supporter of the feudal power (Tomescu, 1968, p. 27). Many books are copied at the order and the donation of the prince, the protagonist being, in most of the cases, Ștefan cel Mare: "Binecinstitorul și de Hristos iubitorul domn Ioan Ștefan voievod, domn al Țării Moldovlahiei, a dat de s-a scris acest Tetraevanghel" (I, 10) (The pious and God lover Stephen the Great, the prince of Moldavia, supported the copying of this Gospel). The princes' desire for paying the writing of books rarely lasts until later centuries. Books were also copied at the order and at the expense of bishops, archbishops and metropolitans: "S-a prescris această sfîntă Evanghelie cu dania și învățătura mitropolitului Teoctist din Suceava" (I, 36) (This Holy Gospel has been copied with the donation and teaching of Teoctist, the Metropolitan of Suceava). But some manuscripts with various subject matters were paid by various boyars, eager to read, to donate them or to collect in their own bookshelves. But they also copy them for the dear ones: "am scris-o [...] fratelui meu mai mic și al doilea" (I, 39) (I copied it for my younger brother), and sometimes manuscripts were copied for the use of the author himself or his children.

The marginal notes contain frequently rhetorical elements by the means of which the copyist is trying to gain the reader's mercy and benevolence; most manuscript writers apologize for the possible mistakes, invoking all sorts of reasons that could cause them. Focused on the addressee, the conative function prevails, most of this type of texts being entitled "predoslovie cătră pravoslavnicii cetitori" (II, 23) (preface to the readers). Behaving as a preface to the mercy of the reader, the transcriber alludes to the hard work he had done, calling himself "cel osîrdnic ostenitoriu" (III, 84) (the one who took great pains) or "iubitorul de ostenele" (II, 428) (fatigue lover). The copyist is also the first who draws attention to the possible error types (during copying or during translation). These refer both to the form and content: "de veți afla vreo greșală, sau alunecarea condeiului, sau cu uimirea minții, sau cu netocmirea cuvintelor sau cu neorthografia meșterșugului, sau ori în ce chip” (II, 439) (if you happen to find a mistake, it is due to the slipping of the pen, or to the absence of the mind, or of the spelling problems). Very interesting are the attempts to justify the errors by a wide diffusion device, especially in the Middle Ages, excusatio propter infirmitatem (Stancu, 2006, p. 131). Extremely diverse, some of them can be clichés, but others are suggestive and original.

A number of reasons invoked by the authors of the manuscripts could form a class of the generally valid truths, very used aphorisms in this type of texts; however, without being trivialized by overuse, these assertions reveal something of the charm of the time. Most of them are expressive metaphors referring to the human imperfection, comparisons containing natural (sky, sea) or divine elements (angels, seraphs, cherubs). We give some examples of these aphorisms: "Căci nime în lume născut nu poate fi negreșit” (III, 193) (No human can be without mistake); "Cum nu este cu putință să fiie ceriul făr-de nouri și marea fără de valuri și pămîntul fără de scîrbe, așa nu este cu putință să nu fie omul fără de greșală” (II, 23) (As it is impossible a sky without clouds and a sea without waves, and the earth without sadness, so it is impossible 
the man to be flawless). It is frequently emphasised the human-divine opposition: "Că eu de îngeri sînt departe; / Că om fiind eu, muritoriu, / N-am putut a fi negreșitoriu” (IV, 76) (I am very different from angels / because, being human / I couldn't have been flawless). Another category of reasons that cause transcription or translation errors refer to authors' physical infirmities. Hieromonk Mitrofan lists "multe neputințe și slăbiciuni” (many infirmities and weaknesses) that cover the writer’s body: "ochii uneori se painjiinesc căutînd, socotind șis numărînd mulțimea cea fără de număr a slovelor. Mîna dreaptă slăbește țiind condeiul; după cap îl doare pentru multa plecare a grumazilor; spatele îl dor, pentru multa plecare gîrbovindu-să; picioarele îi amorțăsc, răvenindu-să de pămînt; pieptul carele să razimă de masa pre care scrie, ca cu cuțite săgetat și pătruns iaste; capul, turburîndu-se creierii, cînd îl rădică în sus să face ca un amețit; scaunul, carele tuturor știut iaste că oricine cînd șade pe scaun odihnă cîștigă, iară scriitoriul nu odihnă, ci zămorîre trupul dobîndește; tot trupul, pînă nu să întinde, nu se îndreptează” (III, 166) (the eyes can't see clearly searching and counting the innumerable multitude of the letters. The right hand weakens because the handling of the pen; the back of the heads hurts him because of the inclined head; his back hurts because of the bending; the legs become numb; leaning on the table, the copyist feels sharp chest pains, as if knives were hurting him; he also feels dizzy when he raises his head because of the intensive thinking; the chair, a resting device for the others, becomes the opposite for the transcriber; the whole body needs stretching in order to straighten).

The age is also quoted to exonerate the copyists. On the one hand, the old age is invoked: "mai vîrtos fiind și la 60 de ani a ticăloasii vîrstii mele" (II, 304) (being of the frail sixty). On the other hand, youth can also be to the detriment of the manuscript. Retrospectively, when they reached the maturity, they notice the transcription errors they had done in their youth. Thus, the deacon-monk Theofil asks forgiveness for the mistakes he has comitted, "fiind în vîrstă tînără și copilărească, mintea abătîndu-să la multe deșărtăciuni” (III, 46) (being young and therefore with a many vanities in mind), being of 69 when he wrote the marginal note. Naturally, weaknesses that generate errors in the manuscript are also mental, spiritual, not just physical. At a first level, the general one, the human condition is inevitably associated with imperfection: “că sînt și eu om pe pămînt, împletit în multe feliuri de păcate” (I, 316) (because I am a sinful earthly creature). Every author describes himself in a negative way: involuntary ("nu din voie ostinenții mele") (not because of my will), the mistakes are made because "nesăvărșirii slabei minții meale" (I, 494) (of my mind imperfections) or of the lack of wisdom (II, 177), of the dullness of the mind due to the sins (II, 254).

The troubled times is another argument that the copyist invokes in order to support him: "că în vremea răzmiriții o am scris, fiind cu muncile împărțite pentru înfricoșări” (III, 526) (I wrote it out during the rebellion). Besides historical inauspicious circumstances, there are various personal troubles: "şi am scris în multă strîmtoare, și în familie și în grea muncă” (I, 39) (I copied it in poverty, in family and in hard work). In other cases the source texts are used as an excuse for the possible errors made during the copying. The Monk Eleazar defends himself: "izvodul a fost neîndreptat și eu spre aceasta neputincios" (I, 35) (the manuscript contained mistakes and I couldn't do anything), so he copied it with difficulty. In other cases the fault lies on the similitude of the letters: "Știu că multe greșale voiu fi făcut, unele pentru asămînările slovelor, precum $a$ de cătră $l, b$ de cătră $v, i$ de cătră $n, e$ de cătră $s^{2}$, care pentru puțina lor despărțire s-au făcut greșală” (III, 612) (I am aware of the many mistakes I made because of the similarity between the letters, as $a$ resembles to $l, b$ resembles to $v, i$ resembles to $n, e$ resembles to $s)$. Last but not least, the haste of the copying has its share of mistakes: "Cetitorul mă va ierta fiindcă cu grăbire am scris" (III, 545) (The reader will forgive me because I wrote in haste).

The copyist asks the reader to forgive his mistakes, in a Christian spirit: "Ca și Dumnezeu să-i dia tot binele, / Aici și în veacul cel viitoriu" (III, 11) (so God will give him all the good in this world and in the other one), in order to get, in his turn, "iertăciune de la preavecinicul și preaputernicul Dumnezeu” (I,

\footnotetext{
${ }^{2}$ Although the correct philological approach would require us to quote Cyrillic, instead of Latin letters, due to the fact that we operated with a most trustworthy edition, we quoted exactly from the corpus in question.
} 
431) (forgiveness from eternal and allmighty God). On the other hand, the manuscript's author asks "pe cine va ceti" (the one who reads) not to judge, but, firstly, "să socotească izvoarele" (I, 259) (to consider the source-manuscripts) which he had used.

Browsing the marginal notes, one can make some observations regarding the translation. Particularly, the interpretation of the sacred content encounters certain difficulties, which are stated by the translator. Most of the texts refer to the laborious effort required by this act: "cu multă trudî și osîrdie le-au scos pre limba românească di pre a greceștii limbă și slovenești” (I, 310) (this has been translated from Greek and Church Slavonic into Romanian with a lot of effort and exhaustion). The one who interprets the text is aware of the fact that translating from one language to another is not a mere content equivalence; so he has to perceive the various shades of meaning, to adjust the translation, to return to a paragraph with further explanations: "La acest rîndișor nu prea lesne să înțălege cum am tălmăcit rumânește fiindcă limba noastră iaste scurtă și puterea cuvîntului ellinesc prea adîncă” (II, 219) (At this specific row the meaning isn't clear in Romanian because our language is too poor and can't grasp the entire signification of the Greek). The author of the translation is criticizing the target-language because of the permanent comparison between the two languages, Greek on the one hand, and Romanian on the other. The conclusion is not flattering the latter: this is a language that has not the exercise of the divine word, whose possibilities have not yet been revealed. The inability of the Romanian words to capture the deep meanings of the Greek words is supplied by an explanation: "Ci pentru ca mai lesne să să înțeleagă, să zicem așa" (in order to be easier understood, we will say like this) (and there follows another possibility of translating). The monk Rafail also translates from "cea prea cu anevoie de tîlmăcit limbă ellinească pre a noastră limbă proastă rumânească" (II, 211) (the Greek, the most difficult to translate); and the metropolitan Veniamin Costachi calls the Romanian "săraca limbă romano-dachicească sau moldovenească” (III, 517) (poor DacianRoman or Moldavian language). In those centuries of cultural agitation, Romanian is not flexible enough to grasp the religious contents. A marginal note from the early $18^{\text {th }}$ century on Codicele Voronețean regards Romanian as unfit for transmitting the meaning of the holy books: "Această carte au fost scrisă pe rumănie şi nu-i bună de nemică” $(I, 466)$ (This book was written in Romanian and it is no good at all). In the $17^{\text {th }}$ century, the common language is still considered incompatible with the abstract religious content, this being transmitted only by the classical languages (Panaitescu, 1971, p. 343); the translation of the holy books from Slavonic into Romanian is a great daring for this century, being regarded with distrust and fear of God's wrath.

The references to Romanian as target-language can be in favour of the national consciousness and unity of language. In most of the cases, the Moldavians regard the language they speak as being Romanian: it has been translated "pre limba rumănească" (I, 500) (into Romanian), it was copied "pe romănie" (I, 488) (in Romanian) or "pre înțelesul rumânescu" (II, 107) (to be understood by Romanians). In Moldavia, various books are translated "spre folosul cel di obști al neamului românesc" (IV, 246) (for the benefit of the Romanians) and not for the Moladavians. The fact that in that time the Moldavian was equal to the Romanian is openly stated by the translations' authors: an Alfavita is "mutată" (moved) from "limba leșească și pre limba noastră moldovenească sau rum(â)nească” (I, 294) (Polish to our Moldavian or Romanian). Most likely, the notion of Moldavian is used interchangeably and with the same meaning as Romanian (Stoicescu, 1983, p. 69), thus proving the unity of the language spoken in Wallachia and in Moldavia, where there was a single ethnic reality: the Romanian one. In the $19^{\text {th }}$ century, the Romanian was the same with the motherland's language: a Tractat dogmatico-polemic "s-au tălmăcit (...) din limba elinească întru a patriei” (IV, 180) (was translated from Greek into the language of our country); Alexandru Beldiman translated The History of the Brave Raimond and Clever Mariana "de pe franțuzasca limbă in limba aceasta a patriei noastre" (III, 623) (from the French into the language of our country).

The wide dissemination of the manuscripts, the numerous copyists and translators prove that, in the mentioned time, there was an intense cultural activity in Moldavia; there was a literary tradition and all those transcribers and clerks formed a class of the scholars (Ciobanu, 1947, p. 124). 


\section{The book's possession}

A significant number of the marginal notes made during the time on the manuscripts and on the printed works inform of the owner of that book. Real "acte de posesiune" (documents of ownership), these exlibrises of the old books make very easy the connection between book and human across time and space (Troia, 2005, p. 5).

Sometimes this type of marginal notes is concise: "S-au făcut proprietate a lui Gheorghe Asachi. 1815” (III, 352) (It is owned by Gheorghe Asachi. 1815). Often, the owner is collective, places of worship or village communities: a Voroavă de intrebări și răspunsuri întru Hristos (București, 1765) is signed: "Din cărțile sf(intei) m(ă)n(ăstirii) Rîșca" (II, 153) (Among the holy monastery's books); "Să (se) știe această sfîntă şi dumnezeiască Pravilă că este a satului, a Colților" (I, 237) (To be known that this Pravilă belongs to the village Colți). During the mentioned period, the marginal records reveal the existence of numerous libraries, both private and clerical. Thus, such patterns are common: "Din numărul cărților arhimandritului Isaia” (III, 161) (From the archimandrite Isaia’s books); "Din biblioteca mea de la Rotopănești” (IV, 233) (From my library from Rotopănești). True book collectors came out: Neofit Scriban, Nicolae Istrati de la Rotopănești, Gheorghe Asachi. A lot of infrapaginal notes are just lists of books that are in the possession of the monasteries. They are real inventories of material goods: "Izvod de toate cărțile și acareturile mari și mici, cîte să află pe lîngă mine” (III, 18) (List of all the books and other material goods which are near by).

Being a material good, the book is subject to economic laws (Chiaburu, 2005, p. 96). The study of marginal notes shows that the price of the books has always held the attention, the notes' authors recording in detail who bought it, from where, and how much the volume cost.

Reading the corpus of marginal notes, it is clear that, in many cases, there were collective efforts to pay for the book. Many marginal notes consist in a list of those who have contributed to that particular volume: a "izvod de cumpărătură" (list of buyers) of a Penticostar notes that "2 lei pol, 6 bani, au dat Mărgăreștii; 1 leu pol au dat Cheptăneștii; 4 pol, 8 bani, au dat Andrei căpitanul Săhăidac, 1 leu pol, 6 pol au dat, amin, streini. Fac 6 lei 8 parale” (II, 18) (Mărgărești family contributed with a part of the amount nedeed to buy the book; the same did Cheptănești family, Andrei Săhăidac and others).

Over the centuries, the prices of the books were expressed in different currencies, developing a rich monetary semantic field. Thus, in the late $15^{\text {th }}$ century until the early $19^{\text {th }}$ century, the prices of the books were paid in all sorts of money, of different origins and different values (aspri, carboave, costande, cruntaliri, florinți, galbeni, groși, lei, ludovici, ruble, parale etc.). The price of the book also involves the action of its sale and purchase. The researcher Elena Chiaburu differentiate the notion of "distribution" from that of "diffusion". Thus, while the first belongs to the economy, assuming "a large amount of the distributed goods and organized structures", the second begins "when the original owner separates from it by sale, donation or inheritance" (Chiaburu, 2005, p. 145). The distribution concerns the immediate moment after the printing of the books, when the final product reaches the recipients.

The main form of distribution was the sale of the prints. The retail of goods directly from the printing house was a usual practice. Cartea românească de învățătură (Iași, 1643) is purchased in the (very) same year "din tîrg din Iași, de la tipariul domnesc" (from Iași, from princely printing house) by "Mierțe și gazda sa, Isipa, și fiul său, popa Ion” (I, 203) (Mierțe and his host Isipa and his son, priest Ion), and the priest "Ioan Vasilovici din Crătești" (Ioan Vasilovici from Crătești) buys a Carte folositoare de suflet (Iași, 1819) “din tipografia sfintei Mitropolii în Moldaviia” (III, 567) (from the printing house of the holy Metropolitan Church of Moldavia). The clergy was also involved in book distribution. Mihalcea Durac "ce au fost logofăt mare" (who was a great chancellor) buys a Carte românească de învățătură for four ducats from "Varlaam mitropolitul Sucevii" (I, 204) (Varlaam the Metropolitan os Suceava) and a Psaltire (Iași, 1807) is purchased "din Tîrgu Iașului, di la poarta mitropolitului, la anu 1807 mai 22" (III, 25) (from Iași, from the metropolitan's gate, on the $22^{\text {nd }}$ of May 1807). The entire church hierarchy was involved in distribution of the religious books especially, which were sold to religious communities, the latter being 
forced to buy. In these notes, the verbs on passive voice "s-au dat" (were given), "s-au împărțit" (were shared) do not refer to the donation, but to the sale, a specific one: compulsory sale. At the metropolitan order, the religious books were sold to villages: a Penticostar (Iași, 7261), printed "cu blagoslovenie și cu toată cheltuiala sfinții sale chir Iacov, fiind mitropolit a toată Moldovlahia" "s-au dat" (with the blessing and at the expense of the metropolitan of the whole Moldavia Iacov was given) to the church from Botești "și au fost orînduiți de au plătit ctitorii și preoții și poporănii" (II, 30) (and the founders and the priests and the villagers had to pay it). The printed works were following the hyerarchic order (Chiaburu, 2005, p. 158), being sent to bishops. A Penticostar (Iași, 1753) "s-au orînduit de măria sa Vodă, cu cheltuiala sfinției sale părintelui mitropolitului Iacov și cu osteneala sfinției sale părintelui episcopului... s-au dat pe la sate" (II, 19) (was given to the villages at voivode's order, at the expense of metropolitan Iacov and with the labour of the bishop). Further on, the printed books were passed through the hands of the archpriests: a Triod (București, 1796) is bought by “oamenii din Straja de la mîna protopopului Toader Rămășcan drept 20 lei” (inhabitants of Straja from the hand of archpriest Toader Rămășcan for 20 Romanian coins). The priests were sometimes the last link of the distribution, taking the books from the districts of archpriests to give them in villages: " $\mathrm{S}$-au dat din porunca stăpînirei duhovnicești la satul Ruseștii Vechi. Blagocin preotul Constantin Cujbă” (IV, 194) (They were given to the village Ruseștii Vechi at order of the clerical authority. Priest Constantin Cujbă). Sometimes the compulsory nature of the purchasing came from the other owner of the printing house, the voivode. An Apostol (Iași, 1756) "și altă carte ci să cheamă Anfologhie" (and another book that is called Anfologhie) are bought in the same year "din porunca mării sale, lui Costandin ficiorul lui Mihai Cehan v(oie)voda" (by the order of His Majesty, Constantin, Mihai Cehan's son), by “noi, oaminii cari mai gios ne-am pus numirile în rîndu” (II, 59) (we, people whose name are written below). Another way of selling books is selling them at the booths situated next to the printing houses or to the Metropolitan Church, sometimes together with other varied goods. Descrierea Moldovei (M-rea Neamț, 1825) is "cumpărată cu cinci lei de la o brașovenie din poarta Mitropolii" (III, 581) (bought for five Romanian coins from a stall / booth at the Metropolitan's gate).

Starting with the second half of the $18^{\text {th }}$ century, marginal texts record books purchased from merchants. Thus, a Liturghie (Iași, 1747) is purchased "de la un vînzător de cărți, Dumitru Lesne, împreună cu alte cărți” (IV, 276) (from a book seller, Dumitru Lesne, along with other books). "Lazăr de pi Tazlău" (Lazar from Tazlău) is certified as a "neguțător de cărți, de li aducea din Țara Rumânească din București și li neguțătorea, adică le vindea mai scumpu aicea în Țara Moldovii” (II, 307) (merchant of books, he brought them from București and he sold them more expensive here, in Moldavia). It is possible they were only itinerant booksellers, fulfilling what Chiaburu (2005, p. 146) calls "circulația populară" (the popular diffusion) and not the institutional one.

The typographs are also agents of the book distribution, selling the copies they have received as payment (Chiaburu, 2005, p. 163). Thus a Triod (Iași, 1747) was bought by "Gheorghii" from "Duca Sotiriovici tipograful” (I, 543) (the typograph Duca Sotirovici) in the same year of publication.

Books can also be sold out at auctions: a Minei "și cu soțiile lor unsprezăci" (and the other eleven tomes) are bought by "jupănul Gheorghie blănar, la sultan-mezat" (III, 383) (the furrier Gheorghe by auction). The fact that a book can be auctioned by the authorities means that it can be also confiscated. This is proved by the marginal notes, underlying, once again, the great value of books during the mentioned period. Some books are seized because of the unpaid taxes: Tîlcuirea liturghiei (Iași, 1697) "s-au luat zaloc de la un popa de la Podoleni, pentru 25 parale, dijma fînului” (II, 103) (was taken as a pledge from a priest in Podoleni for a sum of money, the hay quitrent).

The diffusion of the books begins when "the original owner gives it away by sale, gift, inheritance" (Chiaburu, 2005, p. 145), at a temporal distance from the time of publication. In many cases, the books were sold by individuals belonging to the monastic environment, but also by other various people. Among book buyers there were rural communities: "Acest Pinticostar, dinpreună cu un Minei, le-am cumpărat noi, satul Angheleștii” (III, 132) (This Penticostar, together with a Minei were bought by us, the village Anghelești). Those who contributed to the purchase of books were called "ctitorii sfintii aceștii cărți" (II, 
164) (holy founders of this book) and, almost without exception, the books were donated to the church of the village. Collective efforts to purchase the book are cultural deeds that show a certain attitude and mentality, being an expression of belonging to the same community of language and faith (Danielopolu \& Demény, 1985, p. 121). Places of worship are also loyal buyers of books: a Penticostar (Iași, 1753) "s-au cumpărat de noi, epitropii mănăstirii Sfintului Spiridon, cu bani mănăstirii” (II, 178) (was purchased by us, administrators of the monastery St. Spiridon, with the monastery's money). Private buyers are both clergy and laity with different ranks and functions (in the country or in town). Most often, the book was purchased to be immediately donated "pentru iertarea păcatilor lor, părinților lor și a tot neamul neamurilor lor" (IV, 468) (for the forgiveness of their sins, their parents' and their whole family's). However, in many cases, the book was bought for didactic use: "pentru învăţătura preiubitului fiu al meu" (III, 433) (to teach my beloved son) or it had another purpose: "spre a mea îndeletnicire și folos" (III, 435) (for my work and use); "ca să-i fie odor lui și copiilor lui" (II, 26) (to be treasure for him and his children); the monk Silvestru buys it "fiindcă foarte am iubit a avea cărți pentru mîngîierea mîntuirii sufletului" (II, 353) (because I have always loved to have books for my soul salvation).

The donation of the books - manuscripts or printed-was a widespread phenomenon between the $15^{\text {th }}$ and the $19^{\text {th }}$ century, being both a form of free distribution of books and one of diffusion. The prince's donations or of the high clergy (who received a number of copies when the printed works were published) are cases of free distribution; the other cases of book gift illustrate an aspect of their diffusion and spreading.

The prince's donations have both a cultural and a political importance. An Antologhion (Iași, 1755) is distributed for free "din poronca mării sale lui vodă” "pe la bisărici" (II, 49) (at the order of the prince to the churches), belonging probably to the prince's private supply. The donations go beyond the national borders, establishing cultural connections between the Romanian Principates: "Costandin Mihai Cehan Racoviță voievod, domn și oblăduitor a toată Ungrovlahiei” (the voivode Constantin Mihai Cehan Racoviță, ruler and protector of the entire Wallachia) donates "această sfintă Psaltire iaste afirosită la sfîntul schit ce să numește Oraețul, din județ Neamț” (II, 21) (this holy Psalter to the holy hermitage called Oraețul from Neamț county), or between the Romanian Principates on the one hand and different religious centres (as Athos) on the other. Some of the great prelates distinguished themselves for many donations. The Metropolitan Dosoftei gives Viețile Sfinților (Iași, 1682-1686), "fiind în bejenie printre străini” (being among foreigners) to the Petrid monastery (I, 307). Illustrating cultural relations between Romanian Principates, metropolitans and voivods used to offer each other books printed under their patronage. Thus Dosoftei gives, in his turn, a book received from "sfinţia sa frate, mitropolitul de Ungrovlahia, chir Teodosie" "sfintei Mitropolii ceștii noauă, ce-i zîc Beserica Albă” (I, 294) (His Holiness Teodosie, metropolitan of Wallachia to this holy new metropolitan church called White Church) and "măriia sa Ioan Constandin al doilea B(asarab) voievod, domnul și oblăduitorul Țării Munt(enești)" (His Majesty Ioan Constantin Basarab the second, the lord and protector of Wallachia) gives a Bible "sfinții sale părintelui chir Dosoftei mitropoli(t) T,ărîi Moldovei” (I, 314) (to His Holines Dosoftei, the metropolitan of Moldavia). Low-rank clergymen also donated books, to eachother, to the different places of worship, to the churches or to laity. But the book was also donated by people outside the monastic environment: because Ion, "care au fost slugă" (who was a servant) to Ieroftei "au slujit cu dreptate, [...] au fostu ca un fiu, iar nu slugă” (served with justice, he was like a son and not a servant), he receives from his master "această carte ce s(e) cheamă Psaltire" (I, 414) (this books called Psalter). The donors are extremely numerous, most of the marginal notes having the book as a topic representing the expression of donation; they donate books to churches, schools, individuals, mentors.

Deeply routed in the religious mentality, the book donation is a deed of piety and a devotion gesture (Mazilu, 2001, p. 285) "pentru sufletul morților și sănătate viilor" (I, 443) (for the souls of the deads and for the health of the living people); to be charity for the donors "și feciorilor lor, și părinților, și moșilor și strămoșilor" (I, 446) (and for their sons, and their parents, and their ancestors). But in all societies and all ages the gift is not a dull good, but on the contrary, it necessarily entails the idea of a loan with a 
bearing interest (Mauss, 1993, p. 114). The gift gives to he both "sides" the same nature, creating a mutual connection, very strong for both of them: the recipient (in this case, God) is in a dependent position to the giver (donor) (Mauss, 1993, p. 159) - the first owning the soul salvation to latter. The book donation becomes an intermediary between human being and divinity by remembering and perpetuation of the name of donor. The Christian is sure that, by donating the book to the church he exits the sinner condition and he works for his salvation: "pentru ușurare sufletelor noastre și a părinților noștri, și mai ales pentru răpăusatul fiiu nostru Pașcu” (II, 127) (for the freedom of our souls and our parents and especially for our dead son Pascu); "pentru sufletul mieu" (for my soul) and "a tot neamul nostru în veci, amin" (IV, 76) (for our entire family for eternity, amen). The religious book, a mediator between the man and divinity, becomes an eschatological support "şi să fie ajutor în ziua judecății cumplite" (I, 86) (and to help in the terrible Day of Judgment).

The book was transmitted to the next family generations by inheritance. The children are first who inherit the book: "să fie a feciorilor noștri" (II, 223) (for our sons). But children can not easy inherit the book, restrictive stipulations imposing various conditions. Literacy is one of them: "<Cuvintele lui Teodor Studitul (Rîmnic, 1784)> va rămîne la fii mei care Dumnezău îi va răndui și care dintr-înși va ave evlavie la citire sfintelor cărți, aceluie să rămăi” (III, 610) (<Cuvintele lui Teodor Studitul (Rîmnic, 1784)> will belong to my sons and the one who will be fond of reading holy books, will inherit it). The successors are only males elsewhere, "fetele și ginerii și oricini di partea fetelor treabă cu cartea să nu aibă” (IV, 307) (our daughters and sons-in-law and other related to them won't inherit this book). The girls did not inherit the books (the sons being preferred), but they could receive the book as a dowry if they married a priest: "Această Evanghelie au fost mai înaint(e) vreme a lui popii Racoviță, iar după ce au măritat pe fiica-sa, pe Maria, fata cia mică, s-au dat și cărțăle cîte au fost a preotului (...) ginere-său” (I, 508) (This Gospel belonged before to the priest Racoviță, but after his little daughter, Maria, got married, the books were given to the priest, his-son-in-law).

The books were transmitted from one reader to another by loaning them. Some books are borrowed "pentru treaba învățăturii" (I, 406) (for studies), others for the simply reading: "am avut cinsti să-mi dei dumneaei cucoana Ileana Beldiman acesti istorii s-o cetescu" (III, 594) (I was honoured to have this book for reading from Ileana Beldiman), others to be copied (III , 187).

Being material values as well, the books were often stolen by common thieves or by invaders. A particularly interesting note written by the steward Iordachi who says on the margins of "Leatopisățul Ţării Muntenești” (Wallachian Chronicle), that this tome "a fost al mieu și l-au furat dumn(ealui) Iordachi Balșu vor(nic)" (was mine and it was stolen by the high official Iordache Balş) (therefore a person who is well placed in society). The circumstances in which this theft was comitted are also noted: "Că mi s-a furat acest Letopisăț într-o zi de luni, fiindcă venise și dum(nealui) la casa me”" (This Chronicle was stolen from me on Monday, when he came to my house). Furthermore he says that, despite the fact that he had found it, he does not dare "a-i zice, dumnealui fiind boieru mare și bătrîn" ( II, 10) (to tell him about this, because he is a great and old boyard). He hopes, however, that the boyard, reading the marginal note, will give the book back (to the owner). Another registered thief is "preotul Pintelei ot Sveti Dimitrii" (priest Pintilie from Saint Dumitru) who stole a Penticostar "bisăricii Curălari din Iași” (from the church Curelari in Iași) - found out by "preot Axinte ot Sveti Vasăli” (the priest Axinte from Saint Vasile) and kept by him until he shows it to the metropolitan (II, 390) and a Minei pe luna august gr. (Constantinopole, 1843) from Saint Spiridon “au fost pierdut doi ane și s-au adus iar(ă)și de către fur la an 1856 iunei 17" (IV, 502) (was lost for two years and has been brought back by the thief on the $17^{\text {th }}$ of June 1856).

Sometimes the owner of the book must be established by the law. The Gospel (Bucharest, 1723) purchased both by priest and the villagers produces discontent, so they went to "la sfinția sa Nichifor mitropolit și ne-am giudecat” (II, 74) (law, to His Holiness Metropolitan Nichifor). The typograph Petru Ecard from Cernăuți does not admit he had been given 14 Romainan coins for a Strastnic (Blaj, 1804), "n-au vrut să dea carte aceasta nicecum" (by no means he would give back the book) and "apoi cu mare greutate o au scos Gavriil Ilisăi de la acel vînzător” (III, 288) (hardly did Gabriel Elisei get it from that 
seller).

Many notes contain information about the agitated and strained history of the books which have been bought back. A Tetraevanghel was sent from Humor Monastery in Hungary in order not to fall into the hands of the Tartars. The prince Petru found it there and took it with him in Turkey, "și încă și la Ţarigrad" (and even in Constantinopole) and finally, "dăruit cu cunună împărătească” (because he was gifted with crown) and turned back "în preaslăvita sa cetate de scaun, Suceava” (in Suceava) the book ended its journey, so it got back to Monastery Humor.

\section{The reader}

Some marginal notes-those texts containing additional information to the content of the book-constitute true elements of paratext. Nevertheless, it is a special type of paratext, because all the notes from this category belong to the biographical readers and thus being placed, pragmatically speaking, at an empirical level (Stancu, 2006, p. 85). In the first place, the copyists' marginal notes (they are the first readers of the books they transcribe) by the means of which they try to gain the benevolence of the future readers belong to this category. These texts are, at the same time, both a retrospective view of the reading, and an anticipation of future readings (of some different readers). The copyist speaks ceremoniously to an abstract reader, inviting him, pragmatically speaking, to a dialogue. This is done by using the second person of the verb and pronoun, the imperative, the direct addressing mode with the vocative, the conative function prevailing. In a persuasive rhetorical manner, the "pravoslavnicului cetitori" (II, 21) (orthodox reader) is being clled to be merciful. Some expressions are usual: "cetiţi pre cartea aceasta și cu blîndețe îndireptați”" (I, 260) (read this book and do kindly correct it), “cetind acestea și de veți afla greșit nu vă grăbireț(i) a cleveti, ce îndreptați” (I, 317) (if you happen to find some mistakes while reading this book, don't hurry to defame, but do correct them). It is required not only the kindness, but also the actual participation of the reader in the review and in the correcting of the book. Being challenged to read the book- "Iubite întru Hristos cetitoriule [...] să nu-mi lenevești a ceti și aceste folositoare de suflet” (II, 94) (My beloved reader, I wish you didn't laze and that you would also read this useful pages for the soul) - the copyist relies on an active reader: "Pără aicea am găsit de am izvodit acest Litopisăț, dar de aicea înainte, urmașii mei cercetînd vor afla" (II, 163) (So far I have found and I compiled this Chronicle but from now on my descendants will find out). There is even the possibility that the translator of the book to be influenced by the "pofticioșii cititori" (greedy readers): the readers' interest in that particular book, who "vor căuta pe tomul acesta cu silință" (will read this tome carefully), will give the translator the impulse to also translate the second volume of Halima (III, 209). An extremely critical reader is being warned by Alecu Beldiman that "este lesne a huli, crede-mă, oricari poate / pricină ca să găsască, prin prepus sau cu dreptate" (believe me, it is easy to criticize, anyone can / find false or real reasons to find flaws) but "crede-mă, c-a huli îi drag celui de nemică, / carile c-a fi hulit nu-i pasă, nici ari frică" (believe me, the one who is worthless loves criticizing / the one who has no fear and no care to be criticized) and there is also given a polemical solution: “de nu-ți place lecuire este, ca să nu cetești” (III, 117) (if you don't like it, there is a solution for it: don't read).

Secondly, the marginal notes belonging to the real empirical readers are also elements of paratext. They put down their names (with deliberately humble determiners: "eu, mai nevrednicul între cititori", II, 440 [I, the most unworthy of all the readers]), they want to inform that they have read the book completely ("din scîndură-n scîndură”, II, 252 [from cover to cover]), that they read it over again, they "înțeles ci zîce” (III, 476) (understood what it said) or, on the contrary, "nimică n-am înțeles dintru dînsa” (III, 324) (I understood nothing from it). Sometimes the notes focus on a brief comment upon the content of the respective book. It seems that the recipient has actually accepted the challenge to talk to the author / copyist, he answers him and he will, in his turn, talk to the future readers. Being a consequence of reading, these marginal texts contain small summaries of the volumes, references to their structure, impressions about the importance and the purpose of the book, about the message, about the truth and the fiction 
in the book, reading tips, satisfaction or annoyance caused by the end of the book or other various value judgements. The readers are more and more careful to filter the existing opinions, they critically relate to the content of the book, they systematize the information, express opinions. The discernment shown by some readers (of popular books) is illustrative both for the critical attitude with which they begin to relate to the volume and for the fact that the receiver has become an active instance who comments upon the text and expresses opinions.

Thus the marginal notes contain laudatory parts for the truth of the read volume-the veracity of Archirie and Anadan is asserted by "Simion Popovici ot Borca" (Siomion Popovici from Borca) commiting a fallacious appeal to authority: "Pentru toate cele ci să află aicea scrisă, nimi să nu să îndoiască, căci mii nu-m trebuiește ca să zic minciuni, ci pe cum am aflat de la filosofi cari scrii și sînt vrednici de credință” $(I V, 36)$ (No one should doubt of what is written here, because I do not say lies, but what I learned from reliable philosophers). On the contrary, "Ion Cărji ban" (the high official Ion Cărji) questions the truth of the events narrated in Alexandria: "am isprăvit și eu de citit această cărticică a marelui împărat Alexandru Machedon și de vor fi adevărati toati căti să cuprind, cu adivărat că ești de minuni” (I have finished reading this book of the king Alexander the Great and if all the events narrated here were true, then it is really a miracle), admitting, however, a grain of truth: “însă oaricum tot au fost cevaș” (III, 579) (something must have happened, however). The new taste of reading from other fields, the multiplication of the uncanonically shallow readings make the reader to exclaim, both dramatically and ironically: "Vai mie, înnegritule suflete, pînă cîndu de la răutăți nu mai curmezi! Pînă cîndu vei tot citi la Istorie lui Erotocrit și a Aritusii și altora ca acestora? Cu aceste digrab vei merge la raiu, cu cerga în capu. 1835 ghenar 18" (IV, 113) (Oh me, my blackenned soul, for how long will you be wicked! For how long will you be reading The History of Erotocritos and others like this? These will certainly help you to go to heaven. The $18^{\text {th }}$ of January 1835).

Other notes are brief reviews of the respective books. Istoria lui Zalmis și a Elvirii arouses Catrina Conachi's discontent; after a general opinion, the book being "foarti frumoasă, bini tălmăcită di cumnatu Alecu" (very beautiful and well translated by her brother-in-law Alecu), "dar statornicie acestor doi amorezi au fostu nisuferită, mai vîrtos pentru că dorința loru au rămas fără fericire în sfîrșitu” (III, 594) (but the persistence of these two lovers was unbearable, especially because their desire remained unfulfilled in the end). Sometimes the reader gives clues for reading, for its consequences, for the attitude towards the book, for the spiritual value of the content, referring critically to the book. Reading is instructive (Radosav, 1997, p. 59), and it is also a means of worship: "Această sfîntă carte, Ușa pocăinței, am citit-o cu mare umilință și atîta plăcere am citit, cu foloase cuvinte cele aparte, (...), că eu cu toată seama am citit" (IV, 353) (This holy book, Ușa pocăinței, I read it with great humility and so much pleasure I read those useful words, because I've read very carefully). Sometimes the marginal note indicates a consequence of reading, emphasizing the religious emotion: "și foarte m-am întristat de cuvintele înfricoşatelor munci ale iadului care sînt într-această sfîntă carte” (II, 149) (and I became very sad because of the terrifying agonies of the hell which are described in this book) or giving a further advice for the reader: "și cine se va sili, să o citească cu evlavie" (I, 168) (and the one who will read it, he shall read with piety). Due to both its religious content and its value, reading and copying of the book are deeds that could purify (soul saviour): “și să-l ierte Dumnedzău pe cine au făcut-o sau au cumpărat-o și să mă ierte Dumnedzău și pe mine" (I, 310) (may God forgive those who made the book or who bought it and may God forgive me). "Și cini veți citi aice di la mila lui Dumnezău să aveți daruri și iertare păcatilor” (II, 355) (And who will read here shall enjoy God's kindness and forgiveness of the sins), the reader virtually talking both retrospectively, to the transcriber of the book (he answers to his request to pray for his soul) and prospective, to the future readers.

Another category of notes contain comments referring to the form of the respective book. Thus, a note criticizing the size of the letters, is ironic and funny at the same time: "Acestor slove le trebuie tarniță, căci sînt prea mari: ar putea aduce cu dînsele mălaiu de la țară!" (These letters need a knapsack, because they are too big: they could carry maize from the countryside); the anonymous author of the note addresses 
directly to the copyist in a reproachful tone: "Dar nu-ți iaste mai lesne să le faci mai mici, să nu mînjești cartea, că șeade rău?” ( I, 516) (Isn't it easier for you to make them smaller, not to soil the book, because it looks bad?). In most cases the reader gives a positive answer the transcriber's request to forgive the possible mistakes, but he can also become caustic, criticizing sometimes the translation- "Să vedi că tălmăcitoriul au fost tînăr foarte, căci au poriclit tîlcuirili scriitoriului” (II, 571) (It is obvious that the translator was very young because he changed the author's words).

The writing keeps both the writer and the reader apart, each of them being in his solitude. This aspect is eluded, to some extent, in the marginal notes. The marginal note is a form of dialogue anaphorically oriented to the text that generated it and cataphorically oriented to the subsequent readers. Two aspects become relevant in this context. On the one hand, we can see the intrusion of reality in the fictional text (or on its margins) - in the broad sense of this concept-through the actually biographical reader (copyist, translator, the simple reader), who leaves an undeniable trace through his comments. On the other hand, the book had the intended effect in real world: the fact that the reader noted something after reading means that the text activated at the syntagmatic level of the receiver from semantic virtuality on the paradigmatic axis. These notes, a post reading speech, become for those who will have, in their turn, the volume in their hands, a pre-speech, symbolizing a beginning to communication through time and generations. As a form of intersubjectivity, we notice an ongoing dialogue between text $\Leftrightarrow$ copyist / translator $\Leftrightarrow$ the concrete reader, the chain not being completed even today. We notice a continuous communication between the author and the reader which gives life to the text, which cancels the differences in space and time, to be real means of communication (in a primary sense of the word). The marginal notes also reveal that there is a target audience of the manuscript or the printed work, an informed reader prepared to receive literature (in the broad sense of this notion). And, last but not least, the large number of readers who left their names or impressions shows a continuous reading during the centuries.

\section{The imprecation}

Most of the marginal notes that assure the donation of the book to a place of worship or notify the property contain various curses, these symbolically reinforcing the prestige of the book. Being situated at the intersection between religion and magic, the curse has its roots in the belief in the power of the word. The importance of the imprecation and the various misfortunes summoned against those who would do otherwise turn the curse into a means of pressure with prophylactic value, having a significant impact on the mentality impregnated with the religious spirit, causing, most likely in the first period of the mentioned period, a real fear.

Having in mind the structure, a complete imprecation consists of several parts: the first part records the interdiction to destroy the donation, followed by the pyramidal summoning of the heavenly hierarchies to punish the guilty person, referring also to odious figures in the history of Christianity; the penalty part is also divided into a spiritual punishment as well as a physical one. Of course, the succession is commutative. The pattern of the curse is always adjusted to the imagination, to the creativity. Stereotypes are changed by new elements that give a different aspect to the petrified pattern.

The first meaning of the curse is prohibition. The discourse of the imprecation punishes "stricarea" (the damage) or the waste of the donation in any way; under the curse's consequence will fall those who will "ispiti" "s-o vîndă ori s-o fure" (I, 27) (be tempted to sell or to steal the book), these turning into "(je)fuitori de celi sfinti” (III, 448) (holy thing robbers), those who "se încumetă s-o clintească sau s-o ia de la această sfîntă biserică" (I, 81) (dare to move it or to take it from this holy church), those who will try to destroy, "să rupă argintul" (I, 52) (to break the silvery) of the book "sau să lipsască slovile aceste în vr-un feli și le strice" (I, 327) (or to ruin the letters in it). The curse works not only against the thief, but also against his relatives: "și cini se va ispiti ca să-l furi [...] să fii afurisit pînă la al șaptilea neam, cu tot neamul lui dimpreună” (III, 466) (and those who will be tempted to steal it should be cursed until the seventh generation, together with all his family). The enumeration of the virtual victims of the curse 
turns sometimes into a mirror of the social structure: "Și oricine, din stăpîni, domni, vlădică, potrupop, preut, ctitori, oameni vlădicești, sau oricine, dieci, mireni, de or călca porunca me, blăstămat și anathema va rămîne" (I, 536) (And if anyone breaks my orders, be it master, voivode, bishop, archpriest, priest, founders, or anyone, clerks, laics they will be under curse).

The violation of the prohibition leads to the punishment of the guilty by the divine agents (Tighiliu, 1997, p. 300). In order to fulfil the damnation all the saints and all the church powers are summoned. In general, the centre of the invocation is represented by the curse of the 318 saints (number kept by tradition) of the first ecumenical council summoned by Emperor Constantin the Great-the Council of Nicæa in 325 (Mazilu, 2001, p. 92). In most cases, however, there is an accumulation of forces against committing the evil. At the end of the $17^{\text {th }}$ century and the beginning of the eighteenth century the monk Ioil buys a Gospel and donates it to the church in Poiana Ronci "ce esti a hramului Sf(i)tiai Troiță" (whose protector is The Saint Trinity), protecting it with an imprecation against those who would try to steal it: "să fie blăstămat de Sf(î)nta Troiță și de Maica Precistă și de cei 12 Apostoli și de Sf(i)nți(i) Pro(o)roci și de Sf(i)nții Mucenici și de Prepodobnici și de Precuvioși și de toță sf(i)nți(i) și de cei 318 Oteță Sf(i)nți di Nichiia și de cei 70 de Apostoli și de toț(i) sf(i)nții” (I, 328) (shall he be cursed by The Saint Trinity and by Virgin Mary and by the 12 Apostles and by the holy Prophets and by the holy Martyrs and by all the saints and by 318 Saints from Nicæa and by the 70 Apostles and by all saints).

Being an act of justice, the curse must punish. Thus, a significant part of its structure is constituted by the penalties against those responsible for the theft (Radosav, 1997, p. 74). The lexical violence outlines an imaginary of damnation. The suggested end is death-physical and spiritual, in this world and the after world. In order to cause fear among the virtual culprits, for the world there are drawn suggestive coordinates of an underground geography, the place of the eternal torment, the hell (the aim of the curse being punishment). The divine wrath is completed in punishments by the appealing of the devil. After he would have been "blestemat și nimicit" (cursed and destroyed) by the Evangelists, by the 318 saints from Nicæa and by the 12 Apostles, the eschatological future of the one who had taken the book is together with the "diavolii cei turbați" (I, 156) (mad devils). Failing the Christian destiny, cancelling the chance of deification, the excommunication from the communion with Gods inevitably means a proximity of the opposite world. "Și cine a fura-o să fie al 70 de draci și să fii afurisit și să nu-i aibă Dumnezeu de știre și să fii în iad" (I, 337) (And the one who would steal it shall be with 70 devils and be cursed and God shall ignore him and shall be in hell). Thus, the curse on an Octoib donated by priest Vasca to the church from Rîbna Mare outlines an image of hell full of blazes, darkness and teeth gritting-which lasts even today in people's imagery: the accuser at the Day of Judgment will be "Arhistrategul Mihail" (Mihail archangel) and will be "blestemat, de trei ori blestemat" (cursed, thrice cursed) by the fathers of Nicæa, the trial will obviously be lost: "şi casa lui să fie dată judecăţii Gomorei și sufletul lui iadului celui cumplit, să fie aruncat în focul cel veșnic, unde sînt viermii cei neadormiți și să scrîșnească dinţii lui în întunerecul cel din afară” (I, 182) (and his house shall be given to Gomorrah's fire and the soul to the terrible hell, shall he be thrown into the eternal fire where the tireless worms and his teeth shall grind in the outer darkness). Another possible culprit who "s-ar ispiti să o furi" (would be tempted to steal it) is meant for "cu toț dieavolii împreună să ste la Iad și talpa Iadului să sprijinască în veci de veci” (living with all the devils together with devil's daughter), the curse shiftig to insult: "să fii afurisit în burduhul dracului, amin" (III, 17) (to be damned). We notice in imprecations the concreteness of the imagery which describes the consequences aimed at, the degree of abstracting being reduced, promoting the transparency of the message. The evil is reached in a very concrete way: "Și cine să va ispiti să o furi [...] să miargă în focul nestins și în Tartarul cel mai de desupt, și să lăcuiască în burdeiul Dracului” (IV, 552) (And the one who will be tempted to steal it shall go to the unextinguished fire and in the bottom of the hell and live with the devils). The magic words easily alter to insult (Mazilu, 2001, p. 249) as a safety valve. A Liturghie contains a very violent curse which, most likely, has nothing to do with the theft of the book. The insult-note from 1773 outlines a way of desecration of the imprecation, the loss of the sacre characteristics and stepping into the field of the vulgar profane world: "Pre Radul și cu argatul, să-i ia Dracul și să-i mînince cînii pre cî(m)pi și să fiea 
despărțiit de creștinii” (Shall Radu and his servant be damned and be devoured by dogs in the fields and be separated by Christians), closing symmetrically with "Mînca-l-ur cînii pre Randul (sic!)” (II, 213) (Shall dogs tear into pieces Radu).

To illustrate the wrath of God some detestable figures in the history of Christianity are summoned. The first who is officially cursed (by the Council of Nicæa) is the heretic Arie, a permanent presence in the imprecations from the marginal notes. In the imprecation figures from the Old Testament also appear: Cain, the first fratricide, cursed to be forever wandering, always restless (rendered into a "trembling Cain", a tormenting Parkinson), Korah, Dathan and Abiram, exemplary punished because they rose up against Moses, Christ's betrayer, Judas; it is also cited the leprosy of Gehazi (Mazilu, 2001, p. 372-375). The monk Misail, who purchased and donated a Psalter to Monastery Neamț writes a dramatized and a complex version of the curse: "Iar după moartea mea, cine se va ispiti să îndrăznească să o ia de la această mănăstire sau s-o vîndă în altă parte sau s-o facă să fie a sa, acela să fie blestemat de 318 Părinți cei din Nicheia și să fie la un loc cu Iuda și cu iudeii care au strigat: ia-l, ia-l, răstignește-l, și sîngele lui asupra lor. Și să se afle la judecată cu cel de trei ori blestemat cu Arie și Evnomie și Dioscor și Sevir cel fără cap și să stea la cumplita judecată a lui Hristos de gît cu cei cărora le spune Domnul: plecaţi de la mine, blestemaților, în focul veșnic pregătit diavolului și îngerilor lui și să fie neiertat de noi, în veci, amin” (I, 91) (And after my death, the one who will dare to be tempted to take this book from the monastery or sell it elsewhere or to make it be his, shall he be cursed by the 318 Fathers of Nicæa and be together with Judas and with the Jews who shouted: take him, take him, crucify him, shall his blood be on them. And shall be on trial with the thrice cursed Arie and Evnomie and Dioscorus and the headless Sevir and shall stand at the terrible Judgement of Christ near those to whom the Lord says: Go away from me, you villains in the eternal blaze prepared for the devil and for his angels and shall never be forgiven by us, amen).

Since the $18^{\text {th }}$ century there is a new malediction against those who are guilty: the immortality of the body. For the Christians, the rotting of the body symbolizes the reintegration in the natural order, (re)turning to the constituent elements of the mineral world. In some curses the rotting of the body is invoked, the body of the damned will remain unmelted, unforgiven, the separation from this world being forbidden (T, Tighiliu, 1997, p. 301). The curses that forbid the putrefying of the body generally follow the same patterns, with minimal variations: “[...] Lemnele și hierul și pietrele și tote cîte sînt, să putredzască, dar trupul unuia ca aceluia să nu mai putredzască în vecii veacului, și să aibă pîrîși la vreme giudețul pe Svetii Onofrei, a căruia este hramul aice, amin” (I, 412) (Wood and iron and stones and everything shall rot but the body of that man shall never rot and the accuser at the final judgment should be the protector of this churcth, Saint Onofrei, amen).

The curse from the marginal notes on the old books and manuscripts is at the same time topos and invention. The novelty and the concreteness of the outlined images of some anathemas thrown upon thieves almost raise smiles. So, who would deprive the priest Aron of his Penticostar bought with his own money shall be "să fie afurisit de 318 Sfinți cei din Nicheia și se intre dracul într-însu, să zbiere ca măgariu cînd îl mănîncă lupii” (I, 519) (damned by the 318 Saints from Nicæa and the devil shall posses him, yelling as if he were a donkey devoured by the wolves). Another dramatized and almost amusing version is found in a note from 1853: "Și cine o va fura, în iad va întra și de acolo va striga dracilor, va zici: lase-mă în paci, că ce-am făcut n-oi mai faci” (IV, 447) (And the one who will steal it shall enter the hell and he shall cry to the devils: leave me alone, I won't do any more what I have done). The humour and the rhyme reduce a lot of the soberness of the curse.

\section{Conclusion}

During the mentioned period, the book-printed or manuscript-is a cultural object to which all the layers of the society (literate or not) relate, gathering around it copyists, sellers, buyers, donors, readers etc., being an active and permanent agent of the social progress. It is very appreciated in the mentioned period, on the one hand, because of the biblical content or the monastic environment where the volumes are multi- 
plied, on the other hand due to the great respect for the written word. Compared to ecclesiastical treasures, the references to the book are made almost exclusively with the determiners "sfîntă și dumnezeiască" (holy and divine). The reason why the "small ones" note both significant as well as unimportant facts on the margins of the books is because they are aware of its durability: it is written in order to "be known", the book becoming a bridge between ages. At first, the books are a prerogative of the church, speaking to the individual by the religious service, but, as we advance in time towards (pre)modernity, their content gain a laic character, the book becomes a personal leisure, showing the widening of cultural concerns. Thus, among the copyists, translators, owners, we find people from both monastic environment (monks, priests, bishops, metropolitans), and laity of various ranks and functions.

The tradition of the manuscript was not easily overcome by the printed word. Throughout the mentioned period manuscripts are constant copied, the transcribers having an important role in disseminating the book. The transcribers' signatures are mostly followed by determiners which show their modesty and humility. Defying the boundaries of space and time, there is a complex dialogue between the manuscript author and the reader. The marginal notes outline two types of reader-an abstract one, which is spoken to by a humble copyist, asking forgiveness for the possible mistakes, and the biographical, concrete one, who puts his name on the book. The latter reads the books, re-reads them, he does or doesn't understand the message, compares different books, he forgives the copyist's mistakes, speaks to future readers, in his turn, providing reading tips etc. Sometimes he critically refers to the content of the book, to the author / copyist, thus the book containing its critique.

But the book is also merchandised. The selling and purchasing is the most common means of distribution - the book is sold at printing houses, at booths, and by various merchants, churches and monasteries. However, throughout the Romanian territory and even outside it, there are also other ways of disseminating the book: from generation to generation as inheritance or dowry, as borrowing, as an exchange object, pledge, stolen or re-bought. A very spread fact in the mentioned time is the book donation, the donors being both princes and high clergymen as well as smaller clerics and all kinds of people who don't belong to the monastic environment.

Another aspect that points out the value of the book is its price. Expensive, difficult to be achieved for many, the book needs often a collective effort in order to be purchased.

In the mentioned period the book was a precious object; therefore, it was escorted by a more or less scary curse to protect by the magical power of the word to summon divine and diabolical forces against the one who would break the interdiction of alienation.

\section{Bibliography}

\section{A. Sources}

Însemnări de pe manuscrise şi cărți vechi din Ţara Moldovei, corpus editat de Ioan Caproşu şi Elena Chiaburu, vol. I-IV, Casa Editorială Demiurg, Iași, 2008-2009.

\section{B. Specialized literature}

Barbu, D. (1996). Scrisoare pe nisip. Timpul și privirea în civilizația românească a secolului al XVIII-lea, Antet, București, p. $76-100$.

Chiaburu, E. (2005). Carte și tipar în Țara Moldovei pînă la 1829, Editura Universităţii „Alexandru Ioan Cuza”, Iași, p. $96-163$. Chiperi, M.A. (1996). Vechi însemnări românești ca izvor istoric, Silex, Casă de Editură, Presă și Impresariat, București, p. 13. Ciobanu, Șt. (1947). Istoria literaturii române vechi, vol. I, București, p. 124.

Danielopolu, C. Papacostea \& Demény, L. (1985). Carte şi tipar în societatea românească și sud-estul Europei (secolele XVIIXIX), Editura Eminescu, București, p. 121.

Mauss, M. (1993). Eseu despre dar, în românește de Silviu Lupescu, Institutul European, Iași, p. 114-159.

Mazilu, D.H. (2001). O istorie a blestemului, Polirom, p. 92-375.

Ofrim, Al. (2001). Cheia și Psaltirea. Imaginarul cărții în cultura tradițională românească, Editura Paralela 45, p. 129-213.

Panaitescu, P.P. (1971). Contribuții la istoria culturii românești, Editura Minerva, București, p. 343.

Platon (2011). Phaidros, în românește de Gabriel Liiceanu, Humanitas, București, p. 126 
Radosav, D. (1997). Sentimentul religios la români. O perspectivă istorică (sec. XVII-XX), Editura Dacia, Cluj-Napoca, p. 27131.

Stancu, V.P. (2006). Paratextul. Poetica discursului liminar în comunicarea artistică, Editura Universității „Alexandru Ioan Cuza”, Iași, p. 85-131.

Stoicescu, N. (1983). Unitatea românilor în Evul Mediu, Editura Academiei Republicii Socialiste România, București, p. 69.

Tomescu, M. (1968). Istoria cărții românești de la începuturi pînă la 1918, Editura Științifică, București, p. 27.

Troia, L. (2005). Cartea veche între fascinație și cunoaștere, Princeps Edit, Iași, p. 5.

Țighiliu, I. (1997). Societate și mentalitate în Ţara Românească și Moldova, secolele XV-XVII, Paideia, București, p. 300-301. 